The University of Southern Mississippi The Aquila Digital Community

Faculty Publications

$1-1-1992$

\title{
Quintilius Ethos as Critic of the Poet: Horace, AP 438-44
}

Mark Edward Clark

University of Southern Mississippi

Follow this and additional works at: http://aquila.usm.edu/fac_pubs

Part of the History Commons

\section{Recommended Citation}

Clark, M. E. (1992). Quintilius Ethos as Critic of the Poet: Horace, AP 438-44. Classical World, 85(3), 229-231.

Available at: http://aquila.usm.edu/fac_pubs/6741

This Article is brought to you for free and open access by The Aquila Digital Community. It has been accepted for inclusion in Faculty Publications by an authorized administrator of The Aquila Digital Community. For more information, please contact Joshua.Cromwell@usm.edu. 
(triens), trochee (semis). The interlocutor glibly ends line 328 with a longum $(e u)$-this is Horace's way of letting us peek in on his little game.

A careful reader of Plato, Horace nevertheless seems not to have felt the need for grappling with the school-philosophers in their own palaestrae. Consequently he had much more latitude to decide what to make of his Plato; I think that it is clear that, in many places in the Ars, he addresses primarily the reader who has a close familiarity with the Platonic text. ${ }^{5}$

${ }^{5}$ Much of the above is discussed in my doctoral dissertation (Brown, 1989: Prof. M. C. J. Putnam, director) on Horace's Epistles. I would like to express my gratitude to Prof. William Batstone of The Ohio State University for reading a prior version of this note, for his many helpful suggestions, and for calling my attention to several errors and inconsistencies.

\section{QUINTILIUS' ETHOS AS CRITIC OF THE POET: HORACE, AP 438-44}

At Ars poetica 419-52 Horace argues that the poet's true friend is not a flatterer but a faithful critic of technical error in poetry. To illustrate true friendship, he recalls the criticism of his deceased friend Quintilius Varus (438-44). ${ }^{1}$

Quintilio si quid recitares: 'corrige sodes, hoc' aiebat 'et hoc'. melius te posse negares bis terque expertum frustra: delere iubebat et male tornatos incudi reddere versus. si defendere delictum quam vertere malles, nullum ultra verbum aut operam insumebat inanem, quin sine rivali teque et tua solus amares.

In his commentary on the passage, Brink remarks that Quintilius is depicted here as a "stern" critic whose criticism leads to a climax, "from the courteous corrige sodes, to the preemptory delere iubebat, to the expression of silent contempt." 2 But the difficulty with this interpretation is that it does not fully accord with the context of Quintilius' actions. According to the passage, Quintilius would say (aiebat) correct "this and this", when the poet recited anything to him. Should the poet be unable to improve his verses, Quintilius would enjoin (iubebat) him to delete or rework the poorly turned lines. If the poet preferred to defend his error rather than change his verse (442), however, Quintilius did not waste (insumebat) another word beyond the proper limit

\footnotetext{
'The three iterative verbs here describing Quintilius' critique (aiebat... iubebat ... insumebat) imply that he was already dead by the time the Ars poetica was composed. See C. O. Brink, Horace on Poetry. The Ars Poetica (Cambridge 1971) 413-14.

${ }^{2}$ Brink, 414, 515. R. S. Kilpatrick, The Poetry of Friendship. Horace Epistles I (Edmonton 1986) 21, similarly understands Quintilius as a "severe and uncompromising critic."
} 
(ultra) or argue in vain. In the context of the poet defending his verses, Quintilius' silence is perhaps better understood as an expression of restraint rather than contempt.

This interpretation seems to be supported by Odes 1.24.5-8, where Horace mourns Quintilius' death and describes his friend's character:
Ergo Quintilium perpetuus sopor
urget: cui Pudor et Iustitiae soror
incorrupta Fides nudaque Veritas
quando ullum inveniet parem?

Commentators have noted that Quintilius' "naked Truthfulness" is appropriate for the way Horace portrays his friend in the Ars poetica. ${ }^{3}$ Yet it should be added that Horace here draws attention to a harmony of diverse qualities through the chiasmus of Pudor. . Iustitia. . .Fides. ..Veritas. While each quality would contribute to steadfast friendship (e.g., Justice and Faith), Pudor is noteworthy because in the chiastic balance with Veritas it suggests that Quintilius was known for exhibiting restraint as well as truthfulness. This remarkable balance would accurately fit the description of a truthful friend who knew the limits of his criticism.

If my interpretation is correct, Quintilius' ethos as critic would be consistent with the traditional strictures placed upon the admonition of friends. For example, at De amicitia 91 Cicero asserts that, in contrast to flattery, the exchange of advice is a proper component of true friendship, but he stipulates that admonition must be given in a spirit of freedom, without asperity, and it must be received with patience, not pugnacity (et monere et moneri proprium est verae amicitiae, et alterum libere facere, non aspere, alterum patienter accipere, non repugnanter; see also $\mathrm{Am}$. 88). For Horace's part, the criticism of friends was also a sensitive issue. His plea for friends to show moderation in the criticism of others (Sat. 1.3) and the advice he offers Lollius (Ep. 1.18) are justly recognized today as fundamental to his approach to free speech (libertas). ${ }^{4}$ In the epistle to Lollius, Horace reminds his young friend that freedom of speech is a virtue lying midway between opposing vices (9: virtus est medium vitiorum et utrimque reductum). The two extremes here are the flattery of an obsequious dinner guest who mimics his rich host's words $(10-14)$ and the asperitas agrestis of a disputatious pedant who is obsessed with such trifles as whether goat hair is wool $(6,15-16)$. Horace has little doubt that Lollius will avoid the one error of flattery but he does seem worried that his friend will go to the other extreme of severity. Accordingly, in this letter he classifies unrefined harshness as nearly the greater of the two evils (5: vitium prope maius).

There is every reason to assume that Horace also meant for the principle of the modus to apply to the criticism of a friend's poetry. As much as the censure of moral error, the correction of poetic error could lead to a violation of amicitia, especially if the friend did not allow room for the poet to defend

${ }^{3}$ See R. G. M. Nisbet and M. Hubbard, A Commentary on Horace: Odes Book 1 (Oxford 1970) 279, 284-85.

"See Kilpatrick, 49-55, on Ep. 1.18; and R. L. Hunter, "Horace on Friendship and Free Speech," Hermes 113 (1985) 480-90. 
his verses. ${ }^{5}$ Quintilius seems to have understood the danger and yet was able to fulfill the true friend's obligation of honest criticism. I would suggest that for this reason Horace regarded him as the poet's ideal friend and critic.

\title{
University of Southern Mississippi
} CW 85.3 (1992)

MARK EDWARD CLARK

${ }^{5}$ Brink $(412,514)$ makes the valuable point that Horace was apparently the first literary critic to apply the ethics of amicitia to the criticism of poetry, but he (513) also leaves the impression that Horace saw the friend's criticism of poetry as a rigid process: "At the level envisaged by him the critical operation can be performed only by a like-minded friend. . .Poet and critic must share the same ideals and standards." Brink further notes (417) that the friend's censure of harsh verses and ambitious ornamentation (AP 445-46) is similar to Horace's own criticism of Lucilius' style (Serm. 1.4.8; 1.10.67-71). The portrait of Quintilius does not contradict the view that a consensus of poetic goals was fundamental to the critical process, but it does imply that Horace and his friendly critics did not always agree and that some room for disagreement among friends was expected.

\section{CALL FOR PAPERS}

The Classical Association of the Atlantic States with

The Classical Association of the Empire State

Fall Meeting, October 23-24, 1992, Poughkeepsie, NY

Papers are invited from teachers and advanced graduate students on all aspects of the Classical World and on new methods and resources for improved teaching. Proposals for panels on special topics are encouraged. Abstracts of about $\mathbf{3 0 0}$ words, in triplicate and nameless, should be sent to:

\author{
Dr. John C. Traupman \\ CAAS Conference Coordinator \\ 201 Tower Lane \\ Narberth, PA 19072 \\ (215) 664-5487
}

Length of papers proposed for presentation should be no more than 14 minutes (7 double-spaced sides). Abstracts and proposals for panels on special topics should be submitted as soon as possible, but no later than June 1, 1992. Include a very short curriculum vitae to be used in introducing speakers at the meeting. Topics of wide general interest are preferred. CAAS membership is not required. 